\title{
Open Access to Knowledge: Perceptions of Librarians in Colleges of Education in South-East Nigeria
}

\author{
Ugwuanyi, Adolphus A \\ Federal College of Education (Technical), Umunze-Anambra State, Nigeria \\ Eze Monica Ebere
}

Enugu State College of Education, Enugu-Nigeria

Obi I. C

Federal College of Education (Technical), Umunze-Anambra State, Nigeria

Ugwuanyi E.I,

Department of English Language, Federal College of Education(Technical), Umunze-Nigeria

\section{Doi:10.5901/jesr.2013.v3n4p29}

\begin{abstract}
This paper examined the concept of Open Access and the perception of Librarians in Colleges of Education in South East Zone of Nigeria to Open Access publishing as a medium for delivery of quality Scientific knowledge and for assessing the publications of scholars to global knowledge. The study focused on the Federal and state Colleges of Education in the zone. This is made up of three Federal Colleges of Education and four State Colleges of education respectively. 55 Professional librarians in the seven colleges of education were surveyed. A questionnaire adapted from palmer, et al (2009) was used to collect data. From the survey carried out and the data collected from professional Librarians from the seven colleges of Education across the zone, findings showed that Professional Librarians in the Colleges of education in South East zone have positive perception of Open Access scholarly publishing, though their level of involvement in creating awareness and contributing to the development of Open Access at the time of this study was low. It was also discovered that most of the librarians are yet to understand the concept of Open Access. There is need for improvement in view of the potential benefit of Open Access for promoting the visibility of the research output of researchers in Colleges of Education.
\end{abstract}

Keywords: Access, Knowledge, Perceptions, Librarians, Colleges of Education, South East Zone, Nigeria.

\section{Introduction}

The world has now moved from Industrial Age to the 'Information Age'. The entire world now boasts of knowledge-based and an information driven economy. Current developments point to the dominant role of Information and Communication Technology (ICT) in academic libraries for improved access to information. According to (Anyokoha, 2005), Information and Technology has been sweeping through many profession and library and information services has also left the 
bandwagon effect and are being enriched by the enormous dividends in this revolution. Academic Librarians play important roles in the provision of the required learning, study and research materials and in translating the technology. Access to information by all is now posing a lot of challenges for stakeholders in information sector since its evolution in the $19^{\text {th }}$ century.

Librarians in Colleges of Education are in the business of information to their College Community. In carrying out this business, a lot of activities are involved-accessibility and dissemination of information. Open Access therefore refers to accessibility of all kinds of print that is published and can be accessed through the internet free of charge, since information is an integral part of man's daily activities and existence, therefore access to available information resources or scholarly publication is a global concern to all stakeholders.

In today's global information society, non-literate people are at a permanent disadvantageunsure of their rights, unable to fulfill their potential and unable to play a full part I society. They are disempowered. Information for all is a right and capability that is fundamental to overcoming poverty (Mchombu, 2003). Also the United Nations Development Provision for all when they stated that information for all enhances the knowledge of individuals, which in turns creates opportunities for better realizing their capabilities for improved health, through enabling people to understand and employ preventive strategies and more....To improve income generation and to enhance interaction with the Community (UNDP,2006).

There has been a sea-change in the world of scholarly communication for over a decade. Increasing numbers of academic researchers and policy makers in several countries are embracing the idea that the results of publicly funded research should be as widely available as possible. Open Access is expected to speed up research progress, productivity, and knowledge transfer as well as promoting the democratization of knowledge (Brazier, 2012). To ensure quality assurance of scholarly publishing, models have been developed over the years by stakeholders which now include all authors, editors, reviewers, academic and research institutions, publishers and librarians. Scholarly publishing stakeholders also includes all individuals, agencies and organizations who are committed to intellectual property and copyright. These continuous increase in scholarly publication have challenged a number of scholars to focus their studies on the responsibilities of different stakeholders in the publishing chain. (Omolara and Utulu, 2011).. Open Access to knowledge will no doubt enhance accessibility of available scholarly publication and as well reduce cost effect. In the recent times, the value of libraries reduced drastically as they are no more able to satisfy users with expected scholarly publications they need. Similarly the high cost of subscription rate affects library acquisition (Morris, 2004). A lot of people have carried out studies in the literature on business models and economics of scholarly publishing more especially as it concerns the comparison of the economic model adopted by professional and commercial publishers and open access publishers (SQL 2004); Willinsky, 2009, Conlley and Wooders, 2009), in Omolara and Utulu, 2011. According to International Federation of Library Association (IFLA), information should be made available for all people in line with the principles expressed in the Glasgow Declaration on Libraries, Information services and Intellectual Freedom (IFLA, 2011).

\section{Open access to knowledge}

Open Access means free accessibility of all published knowledge in the world. This includes any kind of print or scholarly publication that is published and can be accessed through the Internet free of charge. A lot of worldwide scholarly journal literature of numerous digital enclaves are protected by various security systems that limits access to kicensed users. All authorities in the field of research are advocating and sensitizing that the global scholarship journal literature be freely available to all regardless of whether the researcher worked at the Harvard or small liberal arts College, or he/she was in the United States or Zambia (Baily, 2006).

The Budapest (2002) Open Access Initiative (BOAI) described open access to knowledge as to mean free availability of scholarly literature and knowledge on the public internet, permitting any 
users to read, download, copy, distribute, print, search, or link to the full tests of those articles, crawl them for indexing, pass them as data to software, or use them for any other lawful purpose, without financial, legal, or technical barriers other than those inseparable form gaining access to the Internet itself. The Budapest Open Access Initiative went further to state that the only constraint on reproduction and distribution, and the only role for copyright in this domain, should be to give others control over the integrity of thir work and the right to be properly acknowledged and cited... In the same manner, Suber (2010), and |Wikipedia (2010) agree with the Budapest Open Access I nitiative, by declaring that open access removes price barriers (fees, licensing, payper-view fees, subscription), legal and permission barriers-copyright restrictions. The BOAL equally agrees that because journal articles need to be disseminated as widely as possible, the new journals will no longer invoke copyright to restrict access to and use of the materials they publish.

Though the Bethesda statement on Open Access Publishing (2003), supports free dissemination of scholarly publication on the public Internet, in contrast to the BOAI, the Bethesda statement introduces the use of a license, specifies the creation of derivative works, and requires the deposit of open access works in digital repositories run by "well established" organizations. Open Access has a number of potential benefits for academic research growth of scholars. The Berlin Declaration (2003) on the Open Access to knowledge is very similar to the Bethesda statement with only minor additions and word changes in its definition, which Suber considers to be the "major public definitions of Open Access" as the "BBB" definition of Open Access". All the advocates of open access however believe that free availability is a mandatory characteristic for it to be feasible.

A lot of people have carried out research on Open Access publishing models, and their economics, impact and quality as a way of disseminating scientific knowledge and accessing the contributions of scholars and researchers. According to Omolara and Utulu (2011), attempts have been made in the literature by proponents of Open Access publishing yardsticks such as those that were used by Bjork and Oorni (2009) to justify how scholarly journals are transforming to accommodate interdisciplinary discourses and the volumes of research contents that scholars produce. Barr and Brazion (2012) see the shift to open access as raising issues for the whole of the scholarly communication process and seek to work with other stakeholder in the process to understand how the whole system can adjust to the major changes which will result from open access to scholarly content in that context. There are equally studies that have been carried out regarding how Open Access publishing is able to manage copyright (Suber, 2004; Kawooya, 2008).

Increasingly numbers of academic research and policy makers in several countries are embracing the idea that the results of publicly funded research should be as wildly available as possible. Most scholarly contributions from Africa are mostly limited to issues on the effects of serials cresis on scholarly publishing in African Continent. The effects of the Africa's dwindling economy on their contributions to global scholarship and knowledge have been assessed. (Altbach and Tefera, 1998). Bibiometric and citation analysis are other areas that have been covered by African scholars regarding scholarly publishing, and are primarily meant to assess the structure of Africa's use of scholarly publications (Adeniran, 1998, Bikainyunai, 2006). Nwaka, (2003), investigated how Nigeria Library and Information Science scholars published their scholarly works.

\section{Purpose of the study}

The general purpose of this work is to find out the perceptions of Librarians in Colleges of Education in South East Nigeria towards Open Access to knowledge. Specifically, the work intends to:

1. Find out the perceptions of professional librarians in shaping the future of scholarly publishing; 
2. Find out the perception of Librarians and their roles in promoting open access in their academic communities

3. Find out perceptions of their roles in creating Open Access in the communities.

4. Find out problems associated with Open Access in the academic communities in colleges of education in South East Nigeria.

\section{Research questions}

1. What are the perceptions of professional librarians in shaping the future of scholarly publishing;

2. What are the perception of Librarians and their roles in promoting open access in their academic communities

3. What are the perceptions of Librarians roles in creating Open Access in the communities.

4. What are the problems associated with Open Access in the academic communities in colleges of education in South East Nigeria.

\section{Methodology}

Area of study is South Eastern Nigeria. Population is all Professional Librarians in Federal and State Colleges of Education in South East Nigeria with a total number of 55 professional librarians. There was no sampling because the population is small. The instrument for data collection was the questionnaire. The questionnaire copies were distributed by hand and some through postal study between January 2013 and March, 2013. In the end, all the 55 copies were returned. The mean was used in analyzing the data. The cutoff point was a measure considered to be "accepted or "agreed while responses before 3.0 were considered rejected or not agreed".

\section{Findings and Discussions}

Table 1. Respondents opinion on the perception of professional librarians in shaping the future of scholarly publishing.

\begin{tabular}{|c|c|c|c|c|c|c|c|c|c|}
\hline $\mathbf{S} / \mathbf{N}$ & Item & SA & $\mathbf{A}$ & UD & D & SD & $\mathbf{N}$ & $\mathbf{X}$ & Remark \\
\hline 1 & $\begin{array}{l}\text { Professional librarians should make } \\
\text { serious effort to shape the future } \\
\text { scholarly publishing. }\end{array}$ & 30 & 10 & 5 & 5 & 5 & 55 & 4.0 & Agreed \\
\hline 2 & $\begin{array}{l}\text { Open access will fail with the active } \\
\text { involvement of professional librarians. }\end{array}$ & 32 & 8 & 8 & 2 & 5 & 55 & 4.2 & Agreed \\
\hline 3 & $\begin{array}{l}\text { The Principles of Open Access relate to } \\
\text { the purpose of professional Librarian. }\end{array}$ & 28 & 12 & 7 & 4 & 4 & 55 & 4.0 & Agreed \\
\hline 4 & $\begin{array}{l}\text { Involvement of Open Access is one way } \\
\text { for Professional Librarians to stay } \\
\text { relevant in the changing information } \\
\text { landscape. }\end{array}$ & 27 & 11 & 6 & 5 & 4 & 55 & 3.83 & Agreed \\
\hline 5 & $\begin{array}{l}\text { Professional Librarian should help } \\
\text { develop impact measurement tools for } \\
\text { Open Access Journals }\end{array}$ & 30 & 10 & 5 & 5 & 5 & 55 & 4.0 & Agreed \\
\hline 6 & $\begin{array}{l}\text { Providing financial resources to support } \\
\text { Pen Access should relocate the existing } \\
\text { resources }\end{array}$ & 36 & 12 & 4 & 5 & 4 & 55 & 4.4 & Agreed \\
\hline 7 & $\begin{array}{l}\text { Professional Librarians should relocate } \\
\text { the existing resources }\end{array}$ & 27 & 12 & 5 & 4 & 5 & 55 & 3.83 & Agreed \\
\hline
\end{tabular}


Table 1 above indicates that majority of the respondents have positive perception of professional Librarians role in shaping the future of scholarly publishing. This stems from the fact that all the questionnaire items in the regard received responses well above 3.0

Table 2: Respondents opinion on the perception of Librarians in promoting Open Access in their academic communities.

\begin{tabular}{|c|c|c|c|c|c|c|c|c|c|}
\hline $\mathbf{S} / \mathbf{N}$ & Item & SA & $\mathbf{A}$ & UD & D & SD & $\mathbf{N}$ & $\mathbf{x}$ & Remark \\
\hline 1 & $\begin{array}{l}\text { Professional librarians should educate } \\
\text { Lecturers about Open Access }\end{array}$ & 31 & 10 & 5 & 5 & 4 & 55 & 4.07 & Agreed \\
\hline 2 & $\begin{array}{l}\text { Principal officers of the academic } \\
\text { communities should be educated on } \\
\text { issues concerning Open Access }\end{array}$ & 28 & 12 & 6 & 4 & 5 & 45 & 4.0 & Agreed \\
\hline 3 & $\begin{array}{l}\text { Issues of copyright as they relate to } \\
\text { publications should be communicated } \\
\text { to academic staff by professional } \\
\text { Librarian }\end{array}$ & 28 & 12 & 10 & 2 & 3 & 55 & 4.16 & Agreed \\
\hline 4 & $\begin{array}{l}\text { Professional Librarians should } \\
\text { encourage Lecturers to publish their } \\
\text { researches in Open Access peer } \\
\text { reviewed Journals }\end{array}$ & 29 & 12 & 5 & 5 & 4 & 55 & 4.01 & Agreed \\
\hline
\end{tabular}

Table 2 above shows that majority of the respondents agreed with the fact that professional Librarians have a lot of roles to play in promoting Open Access to knowledge in their academic communities. This sequal to the fact that all the respondents received mean scores of 3.0 and above.

Table 3: Respondents' opinion on the perception of professional librarians' roles in creating Open Access in their local communities.

\begin{tabular}{|l|l|l|l|l|l|l|l|l|l|}
\hline S/N & Item & SA & A & UD & D & SD & N & X & Remark \\
\hline 1 & $\begin{array}{l}\text { Professional librarians includes } \\
\text { bibliographic records for journal in } \\
\text { their catalogues. }\end{array}$ & 10 & 5 & 5 & 4 & 55 & 4.07 & Agreed \\
\hline 2 & $\begin{array}{l}\text { Professional librarians website should } \\
\text { include link to Open Access Journals. }\end{array}$ & 28 & 12 & 6 & 4 & 5 & 45 & 4.0 & Agreed \\
\hline 3 & $\begin{array}{l}\text { Professional librarians create } \\
\text { professional positions whose main } \\
\text { duties concern Open Access }\end{array}$ & 28 & 12 & 10 & 2 & 3 & 55 & 4.16 & Agreed \\
\hline
\end{tabular}

Table 3 above indicates that respondents are of the view that professional librarians have positive perception about their roles in creating Open Access in their communities. This is sequal to the fact that all the items received positive mean scores.

Table 4: Opinion of respondents on the problems associated with Open Access in the academic communities of Colleges of Education in South East Nigeria.

\begin{tabular}{|l|l|l|l|l|l|l|l|l|l|}
\hline S/N & Item & SA & A & UD & D & SD & N & X & Remark \\
\hline 1 & Inadequate fund & 31 & 10 & 5 & 5 & 4 & 55 & 4.07 & Agreed \\
\hline 2 & Poor power supply & 27 & 13 & 6 & 4 & 5 & 55 & 3.96 & Agreed \\
\hline 3 & $\begin{array}{l}\text { Poor infrastructures (including Internet } \\
\text { communities) }\end{array}$ & 28 & 12 & 10 & 2 & 3 & 55 & 4.16 & Agreed \\
\hline
\end{tabular}


The above table shows respondents opinion on the major problems associated with Open Access in the Colleges of Education in South East Nigeria. The problems of poor state of ICT/Internet connectivity received highest mean score of 4.16 .

\section{Discussion of the finding}

The main findings of this study includes the fact that professional librarians recognized the important of open access to knowledge as one of the emerging issues in knowledge and information management. It is also found out that professional librarian recognized their place in promoting awareness of the Open Access both in their college academic communities and private endeavors as knowledge managers. Their major finding of study is catalogue of problems associate with Open Access. The greatest of these problems is lack of information and communication technologies especially in the area of internet connectivity. The finding of research question agrees entirely with earlier studies of Omolara and Utulu (2011) who observed that Open Access to knowledge enhances accessibility to available scholarly publications. Barr and Brazion (2012) also see Open Access as raising issues for the whoe of the scholarly communication process in which the professional librarian has a lot at stake. The major problems of the Open Access initiative remain inadequate funds, poor power supply and Internet connections. This problems have always recorded in researches. Uwaifo (2012), Unagha and Ugocha 2012 were of the opinion that the greatest challenges of ICT related issues in sub-Saharan Africa is poor power supply.

\section{Recommendations}

In view of the issues and challenges highlighted in this paper, the following recommendations are made.

1. The Federal government of Nigeria should so everything within her power to improve the electricity supply in the country.

2. Professional librarians should be more aware of the potentials of the Open Access in their day to day delivery of services to clientele.

3. Professional librarians should periodically undergo retraining exercise in ICT related courses.

\section{Conclusion}

The Open Access is an emerging phenomenon that should be embraced by all professional librarians. It is a veritable tool for satisfying the clientele. Government at all levels should double their efforts in making sure that the necessary infrastructure is put in place to realize the full potentials of Open Access to knowledge.

\section{References}

Adeniran, O. (1998). Bibliometrics of Computer Science Literature in Nigeria. International Library Review,20(3) 347-359

Altbach, P and D. Teferia (1998) Knowledge Dissemination in Africa: The role of Scholarly Journals Massachnetts: Bellagio Publishing Network.

Anyakoha, E.U. (2005) Issues and Challenges to the Development of Information and Communication Technology in Nigeria Paper Presented at the Federal College of Education (Technical) Umunze Anambra State July-5- $9^{\text {th }}$.

Barr, Bikai-Nyunai (2006) Bradford's Law: Part 1. An Explanatory Approach for Librarians. African Journal of Library, Archives and Information Science. 16(2) 109-122. 
Bjork, B and Oorni, A (2009) A Method for Comparing Scholarly Journals as Service Providers to Authors. Serials Review. 35(2) 62-69.

Budapest Open Access Initiative (BOAI) (2002). Budapest, Hungary: Committee on Open Access

Conlley, J and Wooders, M. (2009). But what have done for me Lately: Commercial Publishing, Scholarly Communication and Open Access. Economic Analysis and Policy, 39(1)71-88.

International Federation of Library Associations (2011) Perception on Open Access. Hague: IFLA.

Kawooya, D (2008) An examination of Institutional Policy on copyright and Access to Research Resources in Uganda.

The International Information and Library Review, 40, 226-235.

Mchombu K (2003) The Challenges Faced by Libraries and Information Centres. www.mbali.info/Doc.221.html. Retrieved April 24, 2013.

Morris, S. (2004) Open Access: How are publishers reacting?. Serial Review, 30 (4) 304-307.

Nwaka, C (2005) Research Publications in Library and Information Science in Nigeira. Publishing to the Wrong Audience?. African J ournal of Library, Archival and Information Science, 13 (2) 93-106

Omolara, M.B and Utulu, S.C.A. (2011) Open Access: Perceptions and Reactions of Academic Librarians in Nigerian Private Universities. African J ournal of Library, Archival and Information Science, 21 (2) 121-131

Palmer, K (2009) where there is a will, there is a way? Survey of academic Librarians Attidudes about Open Access. College and Research Libraries 70 (4) 315-335.

SQL (2004) College and Business Models in Scientific Research Publishing. Cambridgesthire: SQL Itd

Suba, Regazzi (2010) The Shifling Sands of Open Access publishing, a publisher's view. Serial Review 30 (4) 275-280.

United Nations Development Programme (2006). Millennium Development Goals. New York: U.N. 
